\title{
BUYER BEHAVIOUR PATTERNS ON THE PRIMARY HOUSING MARKET IN POZNAN IN THE PERIOD 2010-2011
}

\author{
Maria Trojanek, Assoc. prof. \\ Department of Spatial and Environmental Economics \\ Poznań University of Economics \\ e-mail:m.trojanek@ue.poznan.pl
}

\begin{abstract}
The author endeavoured to define profiles and preferences of buyers on the primary housing market in Poznań. To achieve this aim, the author used data obtained from notarial deeds concerning transactions entered into on the primary housing market in Poznań in the period 2010-2011.

The study was conducted among the biggest groups of buyers (i.e., women, men and married couples $-90 \%$ of those analyzed). The number of transactions encompassed in the study amounted to 1,648 (after selection and rejection of transactions with an incomplete description, e.g., incomplete information in the land register).
\end{abstract}

Keywords: housing market, buyer groups, buyer preferences.

JEL Classification: R21.

Citation: Trojanek M., (2013), "Customer Behaviour Patterns on the Primary Housing Market in Poznan in the Period 2010-2011", Real Estate Management and Valuation, vol. 21, no. 4, pp. 47-53.

DOI: $10.2478 /$ remav-2013-0036.

\section{Introduction}

The demand for certain goods is the amount of a given commodity which buyers can purchase for a defined price and in defined time. Demand is a function of many variables (MILEWSKI and KWIATKOWSKI 2005]. In addition to price, there are other types of factors affecting demand. In relation to the housing market, there is an impact of factors of economic, demographic and social character. Among the factors of demographic and social character, the following are listed in literature: the number of people aged 25-35, marriages, divorces, people living alone, etc. The present research makes an attempt to look more closely at the housing preferences of particular groups of buyers on the primary housing market (Poznań, period of analysis 2010- 2011).

\section{Research method and data source}

In Poland, the vast majority of studies on buyer profiles and preferences as to the housing market have a qualitative character (GEUSZAK 2006; GAWRON 2012; OLEJNIK 2013 ). Surveys, usually targeted, were conducted with the aim of recognizing the potential consumer profile. In the present study, the author made an attempt to use quantitative methods to define revealed preferences. In order to do so, information regarding transactions entered into on the primary market (1,648 transactions) during 2010-2011 was collected. In the studied period, no significant change in the prices of housing in Poznań were observed (TROJANEK 2012; 2013 ), hence prices were not updated for the selected period. Then, using the information recorded in the land registers (section II - ownership and section IV mortgages), the gender and age of the buyers as well as the method of financing property purchases were defined. 


\section{Results}

First of all, the structure of buyers on the primary housing market in Poznań in 2010-2011 was determined (figure 1).

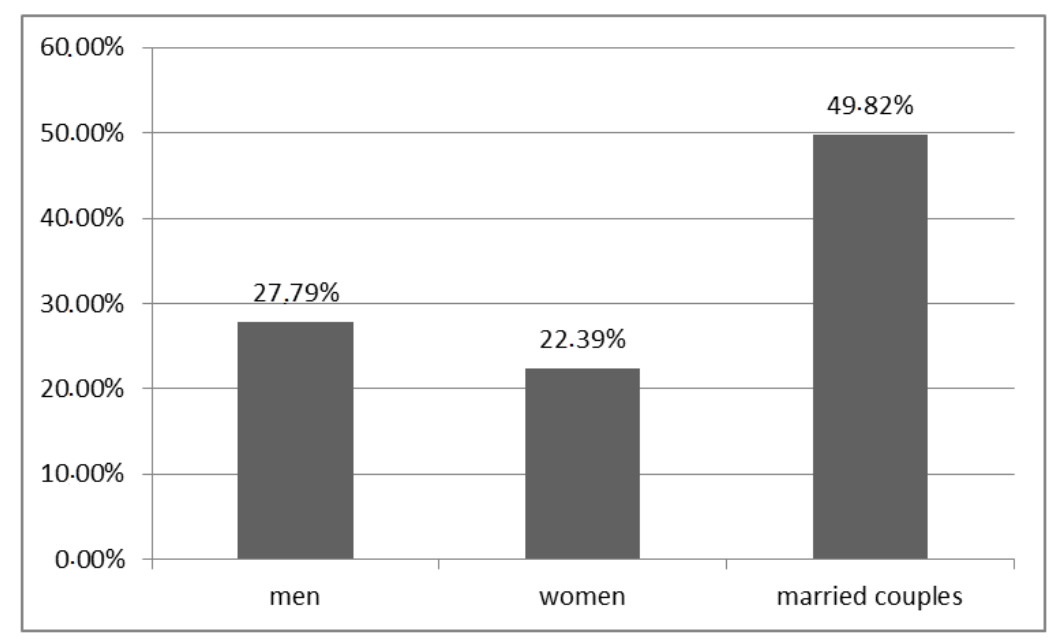

Fig. 1. Structure of buyers on the Poznań housing market in the analyzed groups in 2010-2011. Source: author's own research.

Most of the flats in the analyzed segment of the property market in Poznań were bought by married couples (50\%), with women and men purchasing $28 \%$ and $22 \%$ respectively. Next, the authors analyzed only the biggest groups of buyers (women, men and married couples, as they accounted for $91 \%$ of the transactions in the researched market segment in the analyzed period). The average transaction price and average area of a purchased flat has been presented in table 1 .

Table 1

Average transaction price and average area of flats purchased in Poznań from 2010 to 2011

\begin{tabular}{ccc}
\hline & \multicolumn{2}{c}{ Primary market } \\
\cline { 2 - 3 } & Average price (PLN) & Average area $\left(\mathrm{m}^{2}\right)$ \\
\hline Women & 302460.62 & 51.17 \\
\hline Men & 310671.55 & 51.85 \\
\hline Married couples & 322936.79 & 54.99 \\
\hline
\end{tabular}

Source: based on the author's own research.

Most of the resources on the primary market were spent on flats purchased by married couples. This group of people also bought the biggest flats (about $55 \mathrm{~m}^{2}$ on average). Women in comparison to men tended to spend less on housing and bought smaller flats.

The purchasing power of consumers on the housing market is mainly related to the availability of mortgage loans. During the analyzed period, approximately $65 \%$ of the purchased flats in Poznan were financed with foreign capital ${ }^{1}$ ( $65.5 \%$ on the primary market, $64 \%$ on the secondary market). The percentage share of flats bought by the analyzed groups in the districts of Poznan on the primary market during 2010-2011 is presented in figure 2.

The data presented in figure 2 indicates buyer preferences as to the city districts. On the primary market, women were most willing to buy flats in the Grunwald district, and less willing to buy in the Stare Miasto district than other groups of buyers (around 20\% of the flats purchased by women on the primary market were located in the Grunwald district). In the case of the Jeżyce, Nowe Miasto and Wilda districts, the distributions of transactions among the particular groups of buyers were similar.

\footnotetext{
${ }^{1}$ It means that about $65 \%$ of flats were under mortgage.
} 


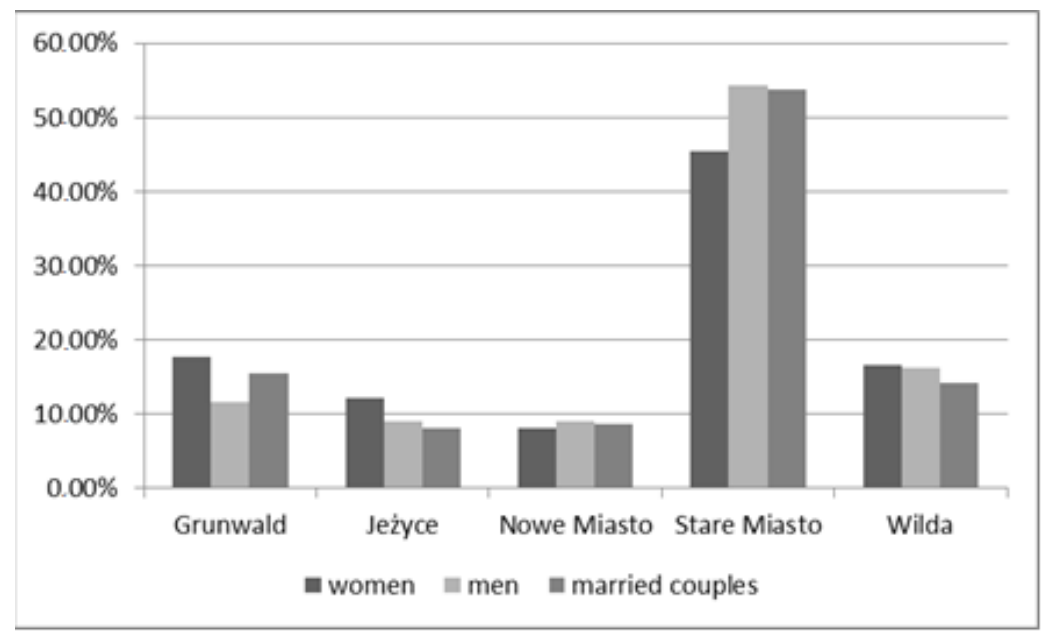

Fig. 2. Percentage share of flats bought by the analyzed groups in the individual districts of Poznan on the primary market in 2010-2011. Source: author's own research.

The distribution of the prices of flats purchased by the analyzed groups of buyers has been presented in figure 3 .

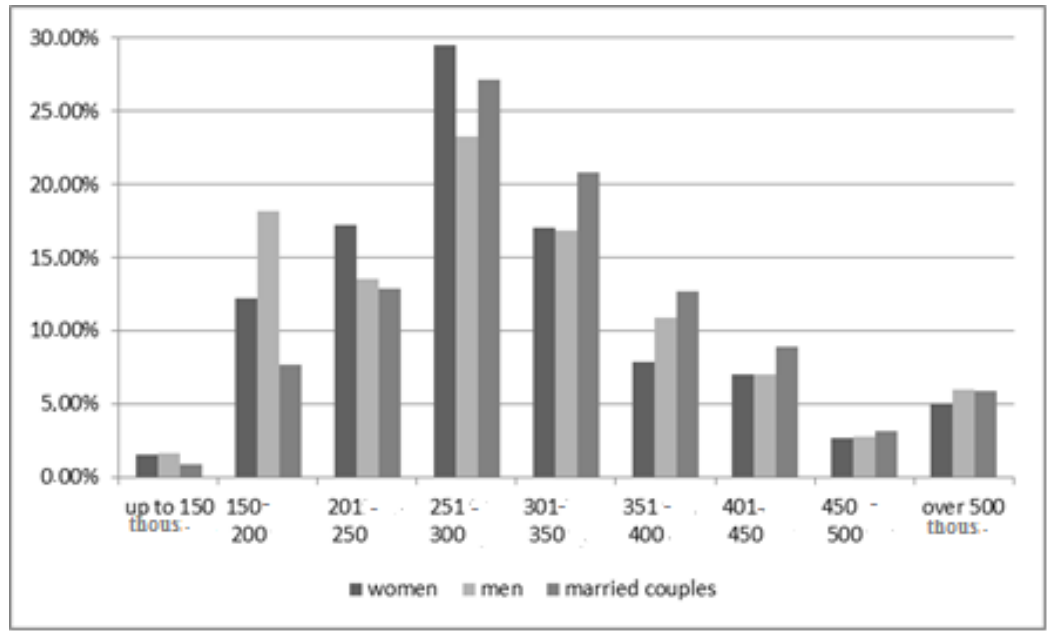

Fig. 3. Distribution of prices of flats bought by the analyzed groups in Poznan on the primary market during 2010-2011. Source: author's own research.

From the analysis of figure 3, we can conclude that the subjects of transactions were most often flats the price of which fell into the range of 201,000 - 350,000 PLN (around $60 \%$ of the transactions). The relatively lowest number of transactions in each of the analyzed groups of buyers concerned flats sold for up to 150,000 PLN. Women most often purchased flats characterized by average prices between 150,000 - 350,000 PLN (around 76\% of the transactions in this group, out of which 30\% regarded the purchase of flats for 251,000 - 300,000 PLN). Men and married couples also bought flats in the price range of 251,000 - 300,000 PLN most often, although the share of these flats was smaller (particularly when men are concerned).

Figure 4 presents the distribution of the buyers' age among the particular groups of buyers entering transactions in Poznań in the period of 2010 - 2011 (in the case of married couples, their average age was established, calculated as the arithmetic mean of the spouses' age).

The analysis of the distribution of the buyers' age (figure 4) indicates that, on the primary market, most of the flats were bought by people aged from 25 to 35. In this age group, most purchases were made by men, who bought $65 \%$ of flats on the primary market. The share of men and women under the age of 25 who bought flats was similar and reached slightly over 10\% for each group. Up to the age of 35, men bought flats more often than women, whereas in the older age groups, the situation was reversed. In the case of married couples, despite using an "artificial measurement" (i.e., the average age of married couples), one can notice that most flats were purchased at an average age of 25 
to 35. In other age groups, the number of purchased flats remained at a similar level, accounting for approximately $10 \%$ of all flats bought by this group of buyers.

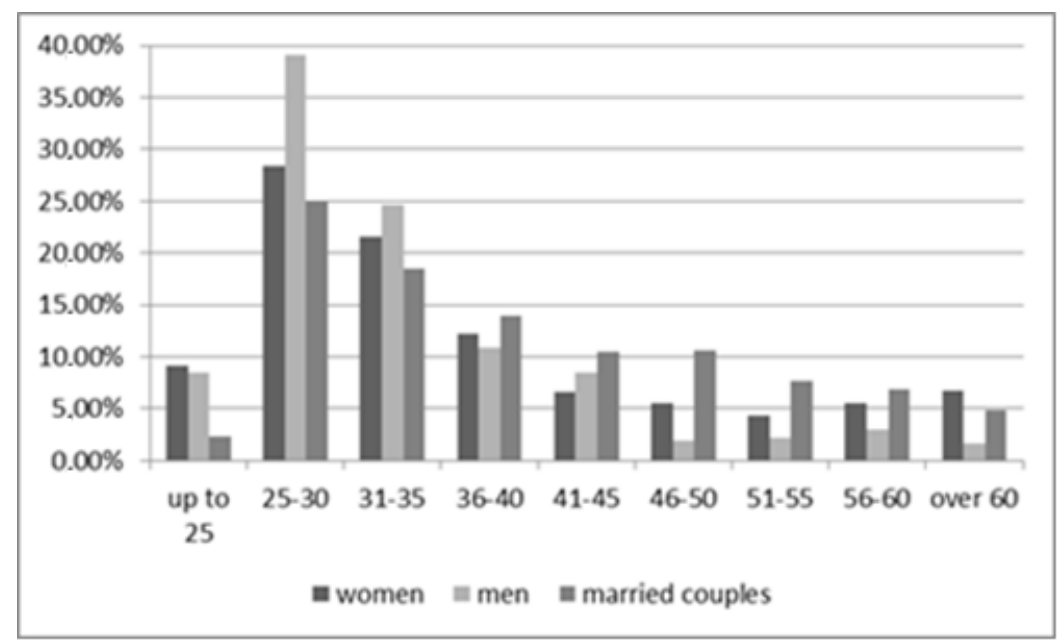

Fig. 4. Age distribution within the particular groups of buyers on the primary market during 2010-3rd quarter of 2011 in Poznan. Source: author's own research.

The structure of purchased flats according to the area and buyers' age in Poznan in the analyzed period has been presented in figures 5, 6 and 7 .

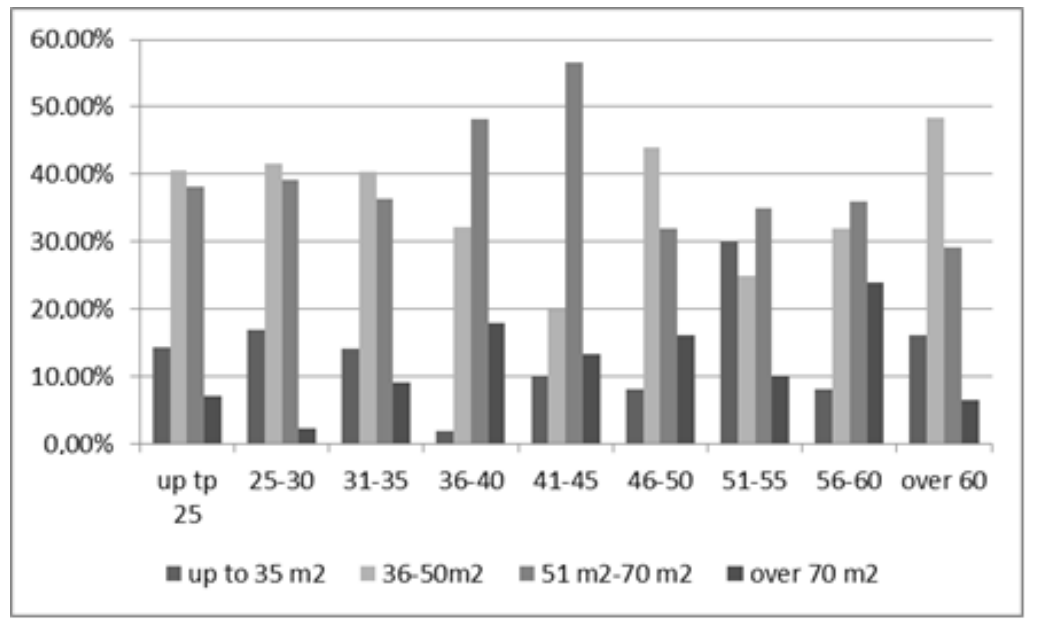

Fig. 5. Area of purchased flat according to buyer's age - women. Source: author's own research.

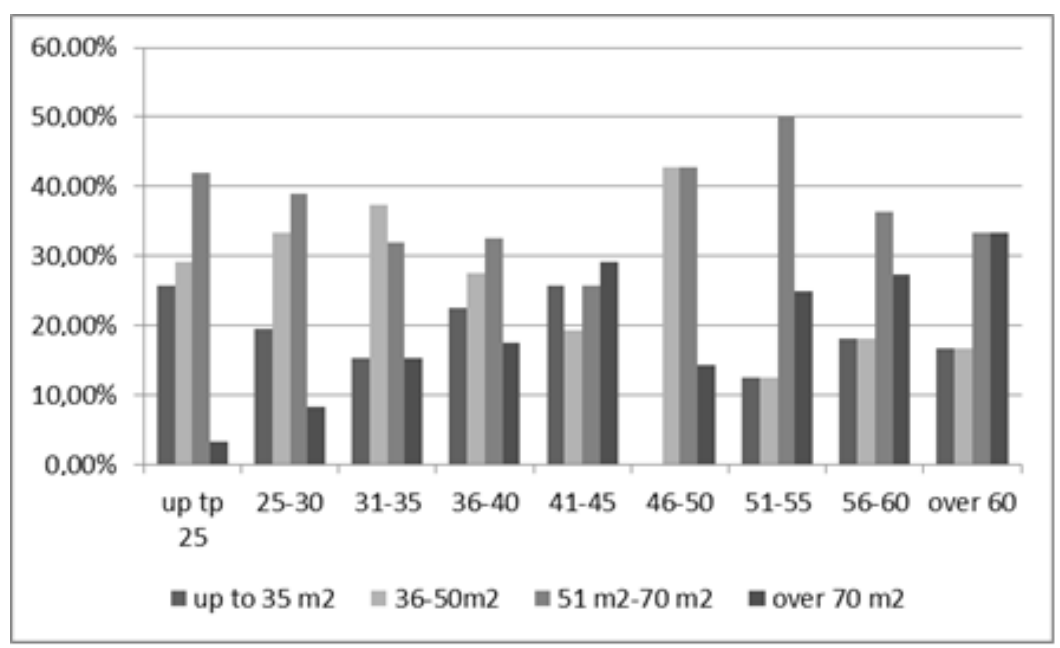

Fig. 6. Area of purchased flat according to buyer's age - men, Source: author's own research. 


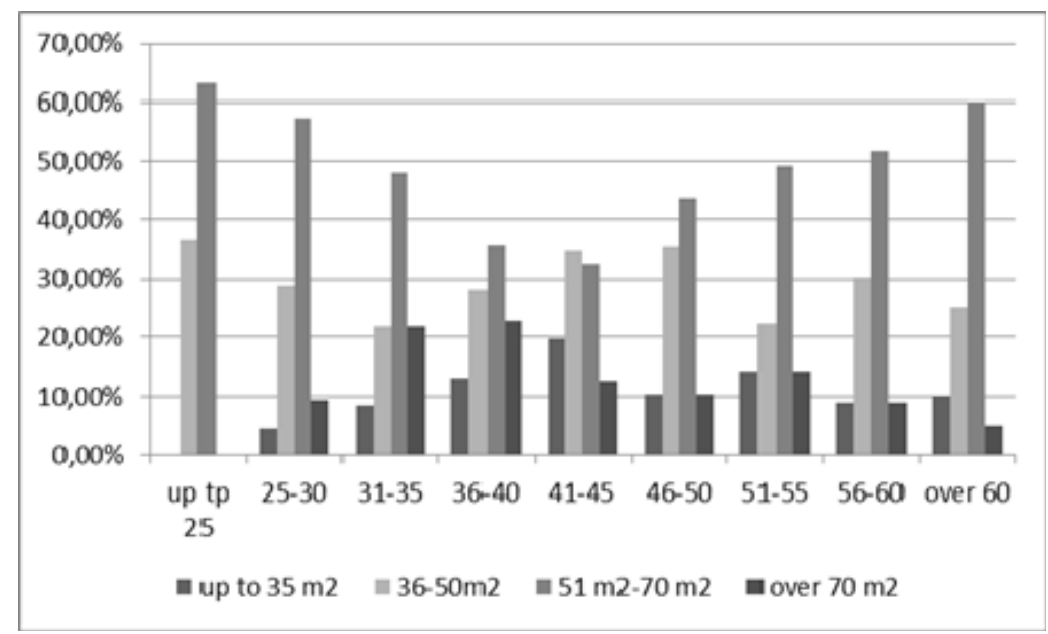

Fig. 7. Area of purchased flat according to buyers' age - married couples. Source: author's own research.

The analysis of figures 5, 6 and 7 provides information on the area of flats purchased by particular groups of buyers. Women tended to buy bigger flats $\left(51-70 \mathrm{~m}^{2}\right)$ more often. As could be expected, small flats of up to $35 \mathrm{~m}^{2}$ were the least popular among married couples. Married couples most often purchased flats ranging from 51 to $70 \mathrm{~m}^{2}$ in terms of surface area.

From the perspective of research, the method of financing the purchase of a flat is of particular interest. In figure 8 , we present the share of flats bought using mortgage loans by particular groups of buyers.

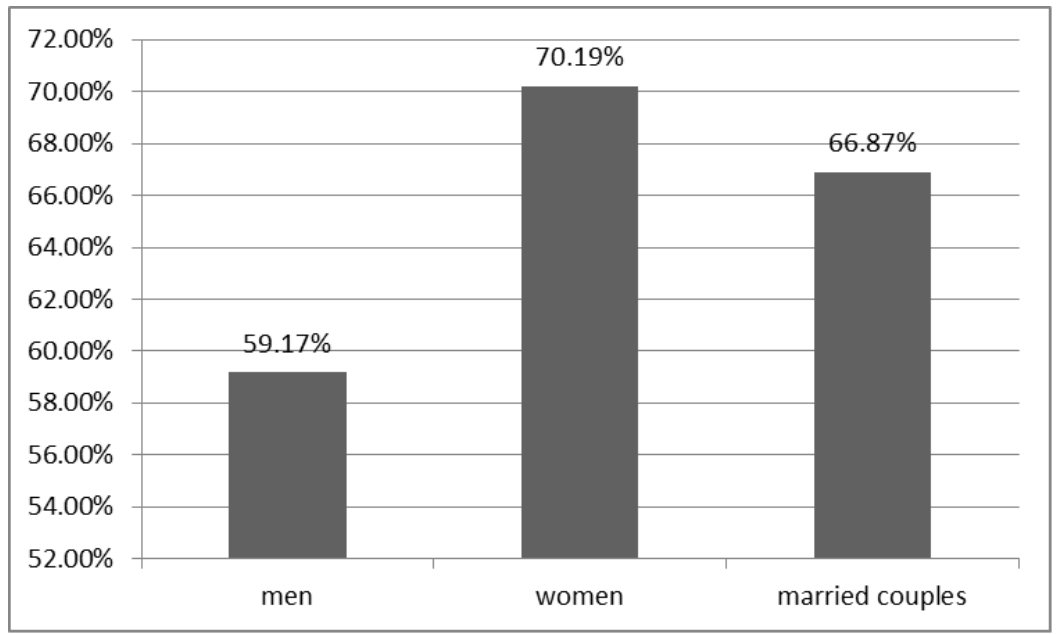

Fig. 8. Percentage share of flats bought using mortgage loans by different groups of buyers on the primary market in Poznań during 2010-2011. Source: author's own research.

Married couples and men revealed the biggest tendency (measured as the ratio of flats financed with a mortgage loan to the total number of flats bought by a specific group of buyers) to take out mortgages in Poznan in the analyzed time period. In the case of both of these groups, around $68 \%$ of flats were bought using loans. Women were less prone to financing their purchase of a flat with a loan (around 59\% did so). In figures 9, 10 and 11, the author presents the share of flats financed by mortgage loans in the particular social groups, taking into account the price of the flat.

From the analysis of figures 9, 10 and 11, we may conclude that, within the studied groups of buyers, small flats costing up to 150,000 PLN were most commonly financed with cash. It is worth mentioning that in the process of purchasing flats, regardless of the transaction amount, women financed such purchases with a mortgage loan less often. 


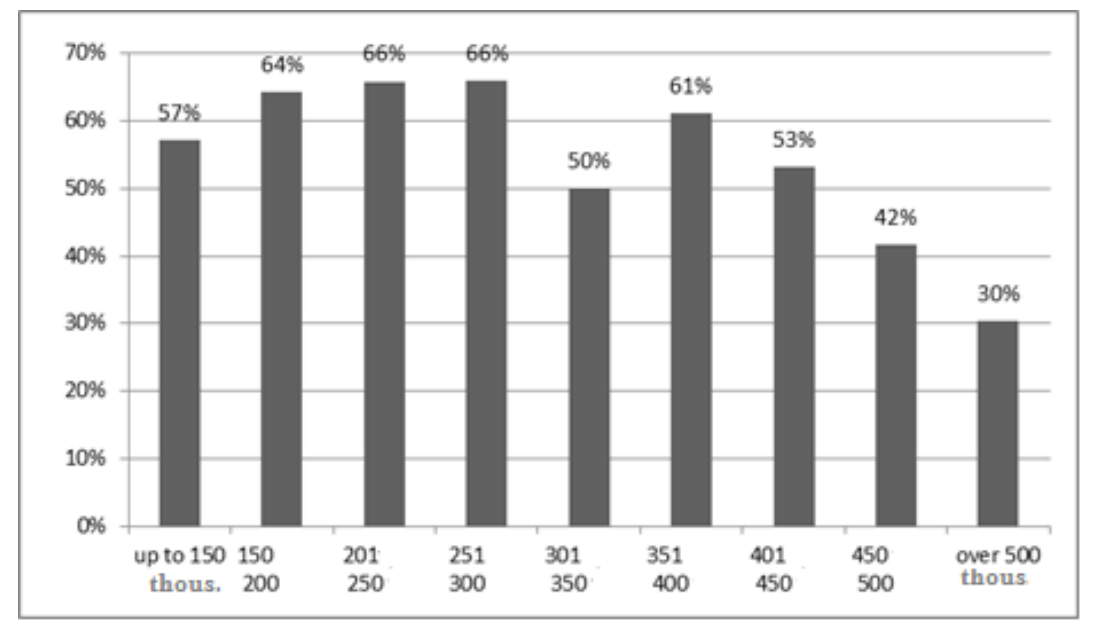

Fig. 9. Percentage share of flats bought by women and financed with mortgage loans in Poznań during 2010-2011, taking into account the price of the flat. Source: author's own research.

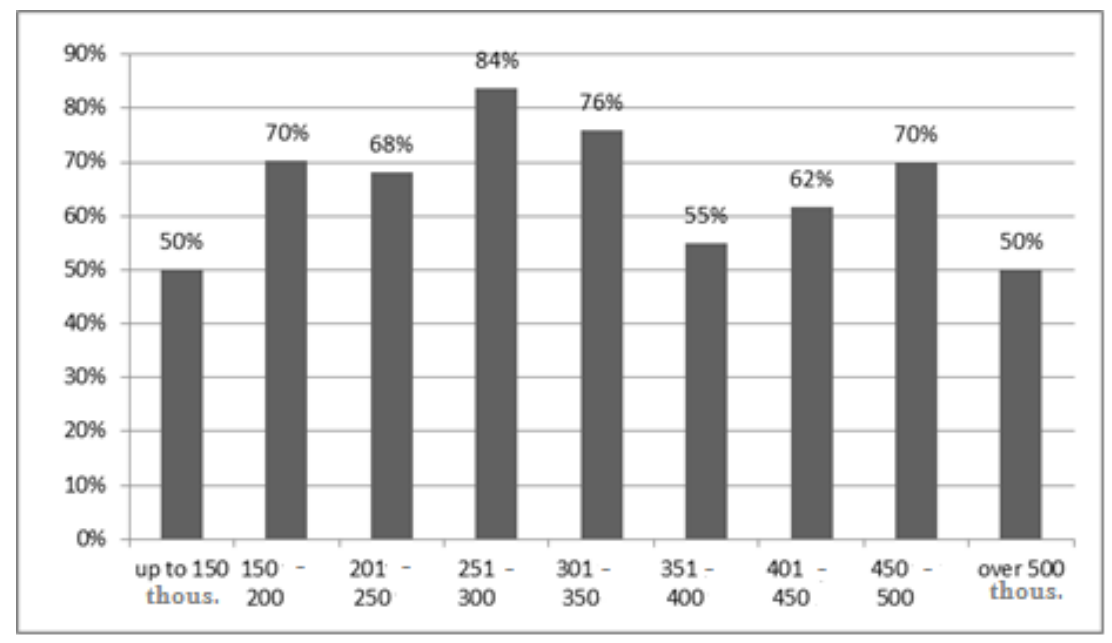

Fig. 10. Percentage share of flats bought by men and financed with mortgage loans in Poznań during 2010-2011, taking into account the price of the flat. Source: author's own research.

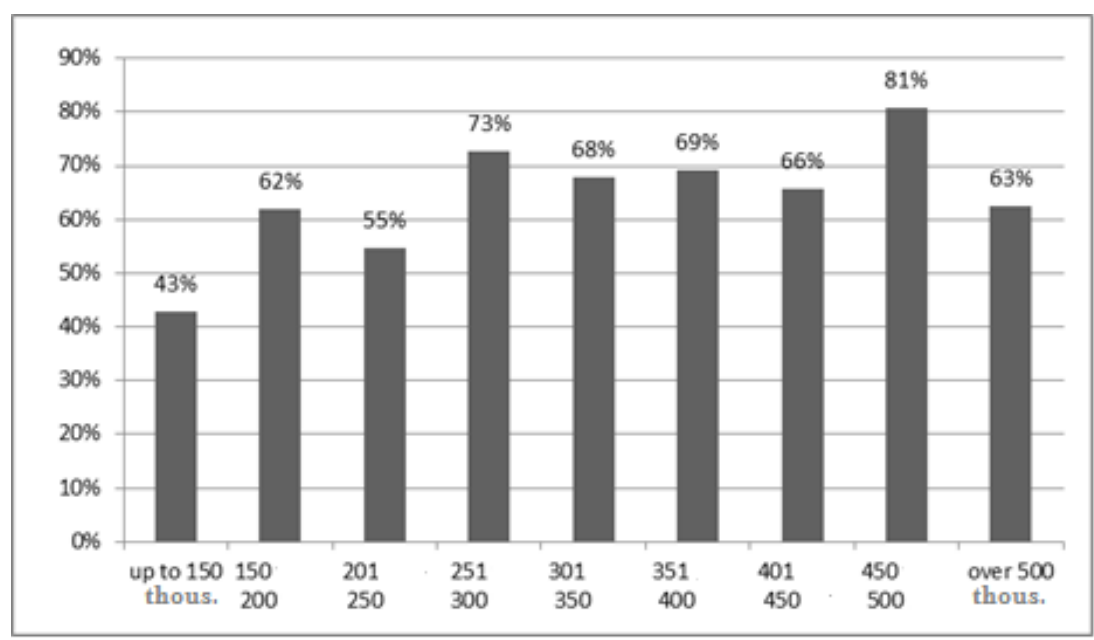

Fig. 11. Percentage share of flats bought by married couples and financed with mortgage loans in Poznan during 2010-2011, taking into account the price of the flat, Source: author's own research. 


\section{Conclusion}

In the study, the author endeavored to define selected features and preferences of buyers on the primary housing market in Poznan. From the conducted analyses, one may conclude that in the period 2010-2011:

- $50 \%$ of the flats were bought by married couples,

- women purchased flats more often than men,

- married couples bought flats with a bigger surface area than other groups of buyers; however, the difference between the area of flats was not significant (approx. $3 \mathrm{~m}^{2}$ ),

- the vast number of flats were bought by people aged from 25 to 35 years,

- the substantial majority of transactions were financed with mortgage loans (from around $60 \%$ of transactions entered into by women to nearly $70 \%$ of transactions made by married couples and men),

- most of the flats purchased (around 60\%) were in the price range of 150,000 - 350,000 PLN,

- flats in the price range of 251,000 - 300,000 PLN were the most popular among the buyers.

The obtained results may become the basis for further discussion on the demographic conditions of demand on the housing market. It appears that they reflect the processes of the change in lifestyle, family models and economic conditions. The observed correlations are significant in the light of ongoing migration processes, as well as the creation of spatial and housing policies.

\section{References}

GAWRON, H., 2012, Potrzeby mieszkaniowe klientów na lokalnym rynku nieruchomości mieszkaniowych $i$ sposoby ich zaspokajania (na przykładzie Poznania), Wydawnictwo Uniwersytetu Ekonomicznego w Poznaniu, Poznań.

GŁUSZAK, M., 2006, Nabywcy mieszkań w Krakowie - preferencje i ich uwarunkowania, Zeszyty Naukowe AE w Krakowie, nr 703.

MILEWSKI, R., , KWIATKOWSKI, G., 2005, Podstawy ekonomii, PWN, Warszawa.

OLEJNIK, I., 2013, Badania preferencji klientów na rynku nieruchomości, in: TROJANEK, M., (red.), Ekonomiczne uwarunkowania decyzji na rynku nieruchomości. Wybrane problemy, Wydawnictwo Uniwersytetu Ekonomicznego w Poznaniu, s. 196-215.

TROJANEK, R., 2012, An analysis of changes in dwelling prices in the biggest cities of Poland in 2008-2012 conducted with the application of the hedonic method, Actual Problems of Economics 2012 no 7.

TROJANEK, R., 2013, Fluctuations of dwellings' prices in the biggest cities in Poland during 1996-2011, Actual Problems of Economics 2013 no 1. 